\title{
DERMOSCOPY OF THE MONTH \\ Dermoscopic Finding of Pigment Network in Lesions of Eruptive Syringoma
}

\author{
Milana IVKOV SIMIĆ ${ }^{1,4 \star}$, Zorica GAJINOV1,4, Milan MATIĆ1,4, Nada VUČKOVIĆ ${ }^{2,4}$, Sonja PRĆIĆ 3,4 \\ ${ }^{1}$ Clinic of Dermatovenereology Diseases, Clinical Center of Vojvodina, Novi Sad, Serbia \\ ${ }^{2}$ Pathology and Histology Center, Department of Pathology, Clinical Center of Vojvodina, Novi Sad, Serbia \\ ${ }^{3}$ Institute for Child and Youth Health Care of Vojvodina, Pediatric Clinic, Novi Sad, Serbia \\ ${ }^{4}$ University of Novi Sad, Faculty of Medicine, Novi Sad, Serbia \\ *Correspondence: Milana Ivkov Simić, E-mail: milana.ivkov-simic@mf.uns.ac.rs
}

UDC 616.5-006.03-076

\begin{abstract}
Syringoma is a benign adnexal tumor derived from intraepidermal eccrine ducts. The usual presentation of syringoma is a small smooth skin-colored, yellowish or brownish papule with flattened or rounded top. Eruptive syringoma is a rarely reported form, where lesions are numerous and occur in successive crops. A case of a 57-year-old Caucasian male with a twenty four-year history of multiple asymptomatic, erythematous and brownish papules, predominantly over the anterior aspect of the trunk is presented. All lesions appeared after prolonged sun exposures within a few days and persisted without further changes afterwards. Contact non-polarized dermoscopy showed a fine light brown, regular pigment network on a light pink background, being the same in all lesions. History of the disease, clinical finding and dermoscopy were inconclusive, and biopsy was performed. Histopathology revealed signs of syringoma. Dermoscopic finding was thought to be intriguing and therefore is discussed in this paper.
\end{abstract}

Key words: Syringoma; Skin Neoplasms; Dermoscopy; Pigmentation Disorders; Skin Diseases; Case Reports

\section{Introduction}

The word syringoma is derived from Greek language syrinx meaning tube. Syringoma is a benign adnexal tumor derived from intraepidermal eccrine ducts $(1,2)$. Although the definition of syringomas as benign neoplasms of the eccrine duct is widely accepted, the pathomechanisms and the genuine neoplastic character of eruptive syringomas are controversial. As reported in two cases by Guitard et al., eruptive syringomas occur as a consequence of chronic inflammatory processes of the skin involving adnexal structures. The authors propose the term "syringomatous dermatitis" to outline the assumed underlying inflammatory reaction because the patients revealed eczematous dermatitis with residual lesions that could be histopathologically diagnosed as an eccrine syringoma $(3,4)$.

There are four major variants as proposed by Friedman and Butler: localized, generalized including eruptive and multiple, familial and associated with Down syndrome (1, 2). Syringoma usually occurs in the eyelid region in females during puberty or early adulthood, rarely later. Eruptive syringomas are a rarely reported form, where lesions are numerous and occur in successive crops (2, 5-12). Most studies emphasize that the diagnosis of syringoma, particularly of eruptive syringoma, have usually not been suspected clinically and the definitive diagnosis is made upon histological examination $(4,6-8,11,12)$. Rare forms and localization of syringoma such as plaque type, presenting as milia, linear, vulvar, penile, chondroid, scalp, acral and solitary over ankle are also reported $(1,2,5-8)$.

Eruptive syringomas are rarely reported and dermoscopic findings are also sparse.

\section{Case Report}

A case of a 57-year-old Caucasian male with the twenty four-year history of generalized 

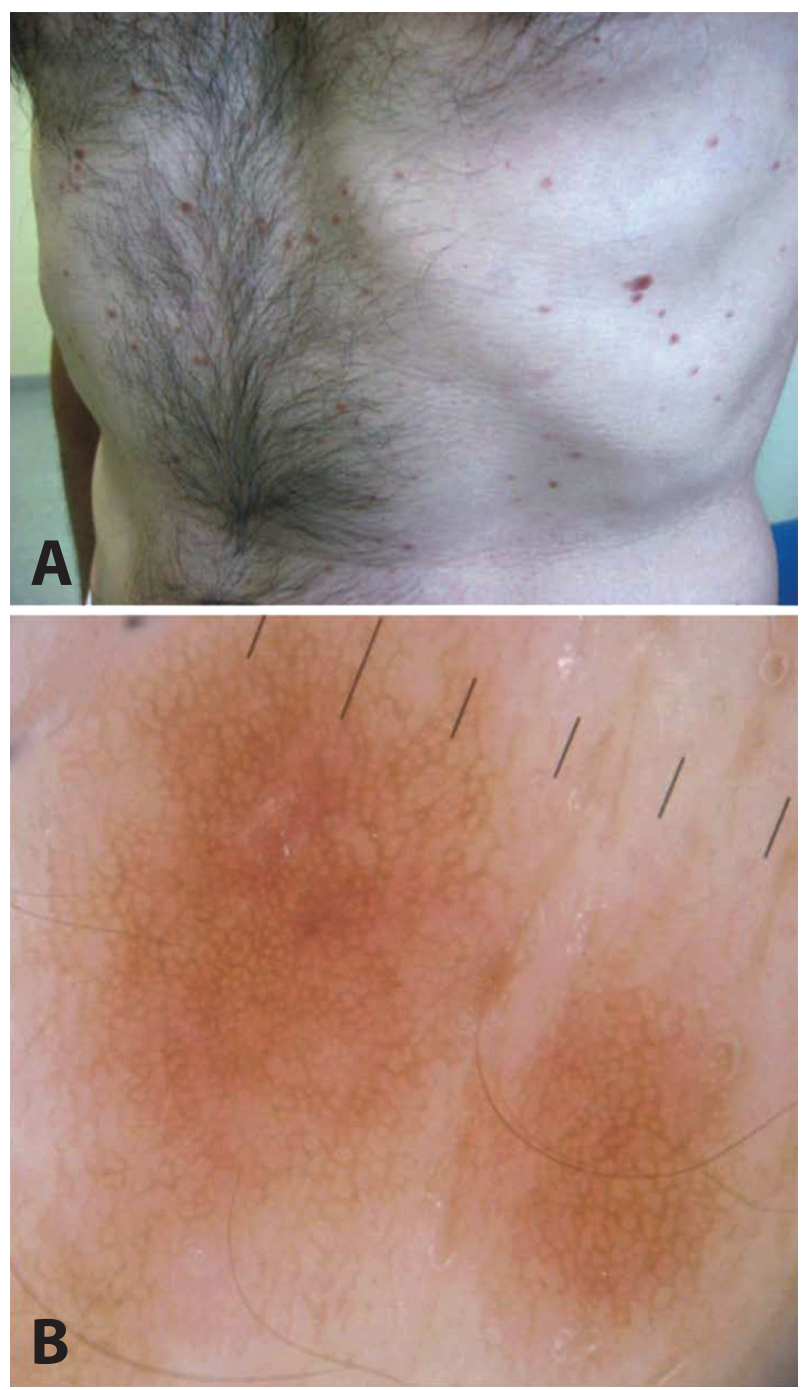

Figure 1. (A) Round to oval, erythematous to brownish papular lesions, slightly shiny, from 2-4 up to $7 \mathrm{~mm}$ indiameter, on the anterior abdomen. (B) On a light pink background, light brown regular pigment network as seen by dermoscopy on two nearby lesions (Delta Heine20, original magnification $\times 10)$.

eruptive syringoma is presented. All lesions appeared after prolonged sun exposure, without sunburns (e.g. blisters, and/or painful erythema following sun exposure) within a few days in the region of the anterior trunk without any subjective symptoms and persisted without further changes afterwards. He is Fitzpatrick skin type III. His previous medical history and basic laboratory findings were unremarkable. He denied use of any medication prior to the development of skin lesions. Family history was negative for
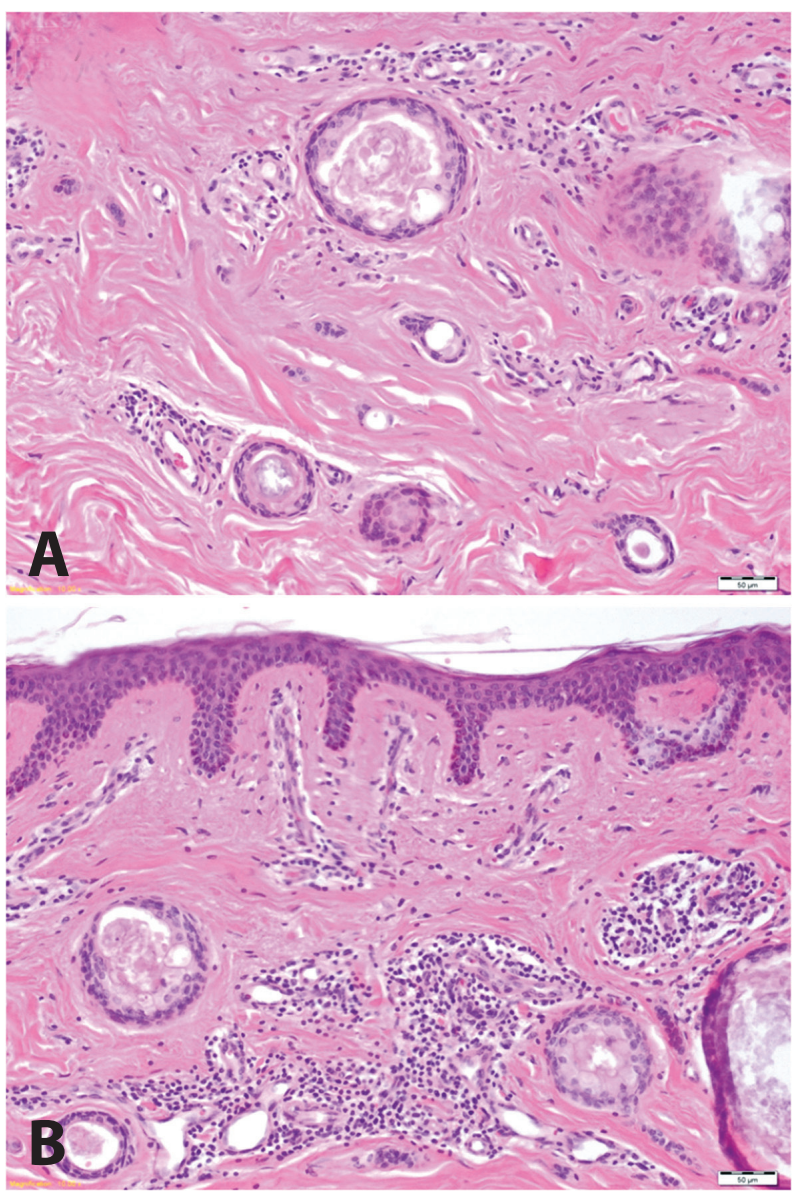

Figure 2. (A) Microphotograph of the skin with circumscribed small aggregates in the superficial dermis of cysts with at least two layers of cuboidal cell with regular nuclei. Some cystic ducts contain eosinophilic material in thelumina. On several ducts there is a visible tennis racket or tadpole process (hematoxylin-eosin stain;original magnification $\times 100)$. (B) Characteristic microphotograph finding of syringoma, with melanin pigment prominent in the basal cellsof the epidermis (hematoxylin-eosin stain; original magnification $\times 100$ ).

similar skin lesions. Clinically we observed around fifty, erythematous-brownish papules, round to oval, their diameter being 2-4 $\mathrm{mm}$ (the largest one was $7 \mathrm{~mm}$ ), slightly shiny on the skin of anterior trunk, axillae and upper arms (Figure 1a). Darier sign was negative. Contact non-polarized dermoscopy was performed with a hand-held Delta Heine 20 dermoscope. The only finding was a fine light brown, regular pigment network on a light pink background, being the same in all lesions (Figure 1b). Digital dermoscopy was performed. Dermoscopic 
finding in our patient was intriguing, suggestive of urticaria pigmentosa. In the superficial dermis histopathology showed circumscribed small aggregates of multiple eccrine ducts lined by up to two layers of cuboidal cells with regular nuclei. Some cystic ducts contained eosinophilic material in the lumina. On several ducts a tennis racket or tadpole-like shape was visible (Figure 2a). Besides, melanin pigment was prominent in the basal cells of the epidermis, reveling signs of basal hyperpigmentation (Figure 2b), which could correspond to dermoscopic finding. It was the only pattern, which looked the same and was visible in all lesions observed in this patient. The patient was reassured about the harmless, benign nature of the condition, and he had not been treated since he had no discomfort or aesthetic problems.

\section{Discussion}

Our patient, except for his male gender, expressed characteristic features of generalized eruptive syringoma such as occurrence in crops, absence of subjective symptoms, distribution of lesions on the trunk and arms with stable course of lesions over time (6-8).

Prolonged exposure to the sun and heat as provocative factors is also in concordance with previous studies $(7,13,14)$.

Dermoscopic finding in our patient was intriguing, suggestive of urticaria pigmentosa $(15,16)$. Pigment network on the light pinkish background was the only dermoscopic finding in our patient. Pigment network is a dermoscopic criterion for melanocytic lesions, but it can also be detected in non-melanocytic lesions such as mastocytosis, dermatofibroma, solar lentigo, pigmented seborrheic keratoses, accessory nipple, Kaposi sarcoma, and even healthy skin (15). Recent histopathological reports of syringomas showed basal hyperpigmentation in various but important percentages of lesions in addition to other features $(5,7,8)$. Patrizi et al. noted hyperpigmentation in the basal layers in $12(41.2 \%)$ patients, being more frequent in eruptive syringomas in 9 patients (5). Lee et al. analyzed 61 patients and reported basal hyperpigmentation in $26.2 \%$ of them (7). Ghanadan et al. reported cases of 34 patients with basal hyperpigmentation in $86.6 \%$ of localized syringomas and in $73.6 \%$ of the generalized form (8). In their case of unilateral linear syringoma
Hayashi et al. observed on histopathological examination a slight thickening of the rete ridges with basal melanosis with characteristic features of syringoma in dermis. They connected dermoscopic finding of a very faint light brown color pigment network that was observed in their case with basal melanosis alone. They speculated that fibrotic stroma in syringoma might cause epidermal thickening and basal melanosis, which would correspond to a delicate pigment network, as often shown in dermatofibroma (11).

We share the opinion of Hayashi et al. that dermoscopic finding of regular light brown pigment is not likely to be the specific finding caused by tumor structure itself, but rather non-specific consequence of basal layer pigmentation that overlie deeper tumor structure. Moreover, that finding could potentially favor an underlying inflammatory reaction and proposed "syringomatous dermatitis" that is one of points of view to the proposed pathomechanisms of syringomas. Prolonged sun and heat exposure may have been provocative factors that triggered such an inflammatory reaction and resulted in eruptive syrinogomas in our patient.

\section{Conclusion}

We can conclude that eruptive syringoma can in some cases be included in the differential diagnosis of melanocytic lesions and non-melanocytic skin lesions with the dermoscopic appearance of a regular pigment network. Future reports and studies on this subject are needed.

\section{References}

1. Friedman SJ, Butler DF. Syringoma presenting as milia. J Am Acad Dermatol. 1987;16(2 Pt 1):310-4.

2. Avhad G, Ghuge P, Jerajani HR. Generalized eruptive syringoma. Indian J Dermatol. 2015;60(2):214.

3. Guitart J, Rosenbaum MM, Requena L. 'Eruptive syringoma': a misnomer for a reactive eccrine gland ductal proliferation? J Cutan Pathol. 2003;30(3):202-5.

4. Müller CS, Tilgen W, Pföhler C. Clinicopathological diversity of syringomas. A study on current clinical and histopathologic concepts. Dermatoendocrinol. 2009;1(6):282-8.

5. Patrizi A, Neri I, Marzaduri S, Varotti E, Passarini B. Syringoma: a review of twenty-nine cases. Acta Derm Venereol. 1998;78(6):460-2. 
6. Soler-Carrillo J, Estrach T, Mascaró JM. Eruptive syringoma: 27 new cases and review of the literature. $J$ Eur Acad Dermatol Venereol. 2001;15(3):242-6.

7. Lee JH, Chang JY, Lee KH. Syringoma: a clinicopathologic and immunohistologic study and results of treatment. Yonsei Med J. 2007;48(1):35-40.

8. Ghanadan A, Khosravi M. Cutaneous syringoma: a clinicopathologic study of 34 new cases and review of the literature. Indian J Dermatol. 2013;58(4):326.

9. Yoshii N, Kanekura T, Churei H, Kanzaki T. Syringomalike eccrine sweat duct proliferation induced by radiation. J Dermatol. 2006;33(1):36-9.

10. Teixeira M, Ferreira M, Machado S, Alves R, Selores M. Eruptive syringomas. Dermatol Online J. 2005;11(3):34.

11. Hayashi Y, Tanaka M, Nakajima S, Ozeki M, Inoue T, Ishizaki $S$, et al. Unilateral linear syringoma in a Japanese female: dermoscopic differentiation from lichen planus linearis. Dermatol Reports. 2011;3(3):e42.
12. Kutlu Haytoḡlu NS, Kartal S, Kiremitci U, Gurel MS, Pașoḡlu E. Adult onset eruptive syringoma. Istanbul Med J. 2012;13(3):141-4.

13. Huang YH, Chuang YH, Kuo TT, Yang LC, Hong HS. Vulvar syringoma: a clinicopathologic and immunohistologic study of 18 patients and results of treatment. J Am Acad Dermatol. 2003;48(5):735-9.

14. Sanchez TS, Dauden E, Casas AP, Garcia-Diez A. Eruptive pruritic syringomas: treatment with topical atropine. J Am Acad Dermatol. 2001;44(1):148-9.

15. Vano-Galvan S, Álvarez-Twose I, De las Heras E, Morgado JM, Matito A, Sánchez-Muñoz L, et al. Dermoscopic features of skin lesions in patients with mastocytosis. Arch Dermatol. 2011;147(8):932-40.

16. Akay BN, Kittler H, Sanli H, Harmankaya K, Anadolu R. Dermatoscopic findings of cutaneous mastocytosis. Dermatology. 2009;218(3):226-30.

\section{Dermoskopski nalaz pigmentne mreže kod lezija eruptivnog siringoma}

\section{Sažetak}

Siringomi su benigni adneksalni tumori, porekla intraepidermalnog dela ekrinih žlezda. Najčešće su u vidu papula boje kože, žućkaste ili braonkaste, glatke, zaravnjene ili zaobljene površine. Eruputivni siringomi su ređe opisivani oblik siringoma. Kod ovog oblika se javljaju brojne lezije koje nastaju u „naletima“. Prikazujemo muškarca starosti 57 godina, bele rase. Promene na koži nastale su nakon dužeg izlaganja suncu, bez opekotina, u vidu eritematozno braonkastih papula domi- nantno na trupu, bez subjektivnih simptoma; od kada su nastale perzistiraju nepromenjene tokom 24 godine. Lezije su pregledane i kontaktnom dermoskopijom, pri čemu je uočena svetlobraon, delikatna, pravilna pigmentna mreža na svetloružičastoj osnovi. Anamneza, klinička slika i dermoskopski nalaz nisu doveli do definitivne dijagnoze, te je urađena biopsija lezije i histopatološki nalaz je ukazao na siringome. Dermoskopski nalaz je bio intrigantan i prodiskutovan je u radu.

Ključne reči: Siringomi; Kožne neoplazme; Dermoskopija; Poremećaji pigmentacije; Kožne bolesti; Prikazi slučajeva 